\title{
TELEVISION AS A HYBRID REPERTOIRE OF MEMORY
}

\author{
NEW DYNAMIC PRACTICES OF CULTURAL \\ MEMORY IN THE MULTI-PLATFORM ERA
}

\author{
Berber Hagedoorn \\ Department of Media and Culture Studies \\ Faculty of Humanities, Utrecht University \\ Muntstraat 2A \\ $3512 \mathrm{EV}$, Utrecht \\ The Netherlands \\ b.hagedoorn@uu.nl
}

\begin{abstract}
In this article, television is reconsidered as a hybrid 'repertoire' of memory. It is demonstrated how new dynamic production and scheduling practices in connection with highly accessible and participatory forms of user engagement offer opportunities for television users to engage with the past, and how such practices affect television as a practice of memory. The media platform Holland Doc is discussed as a principal case study. By adopting and expanding Aleida Assmann's model of the dynamics of cultural memory between remembering and forgetting, a new model to study television as cultural memory is proposed which represents the medium's hybridity in the multi-platform era.
\end{abstract}

Keywords: television in transition, cultural memory, hybridity, repertoire, scheduling, digital thematic channel, multi-platform

In the current multi-platform era, in which we are witnessing a vast growth of new media and digital technologies, the medium of television has been transformed. No longer limited to a relatively stable technology and practice, 'television' is a more complex constellation of dynamic screen practices. Programmes are transmitted on numerous platforms and screens via a variety of distribution and storage formats, and as such, 'television no longer refers exclusively to a single technological medium'. ${ }^{1}$ Television functions more as a connected experience where 'traditional' broadcasting is mixed in with digital culture, for instance via the internet, mobile technology, digital thematic channels and DVD. This is exemplified by the first 'multi-platform' Olympics where audience attention for BBC programming was dispersed in a relatively even manner across all four screens (PC, mobile, tablet and connected TV). 
Television today (next to other media practices from film to digital archives, social media and mobile technology) functions as an increasingly complex 'tool' helping us to remember and preserve the past. ${ }^{2}$ In the present era of convergence, television's hybridity is further expanded and renewed in connection to digital media technologies. Hybridity occurs 'when one cultural space absorbs and transforms elements from another'. ${ }^{3}$ In the current media landscape, where television viewers/users are actively searching for and making connections with content across a range of platforms, television's hybridity is more and more a part of dynamic production practices in connection with highly accessible and participatory forms of user engagement. How do new dynamic practices offer opportunities for television users to engage with the past and how do such practices affect television as a practice of memory? While the medium of television has still not received the same attention in memory studies compared to literature, film, photography and cultural studies, recent studies and international conferences have started to demonstrate the crucial role of television in the everyday process of remembering and forgetting. ${ }^{4}$ Aleida Assmann makes an important distinction between remembering and forgetting as both active and passive processes, arguing that ' $[$ t] between the pastness of the past and its presence is an important key to understanding the dynamics of cultural memory. ${ }^{.5}$ Assmann's model of cultural memory (Figure 1) provides insight into this tension and is a crucial instrument to a deeper understanding of cultural memory as the interplay of present and past in socio-cultural contexts. ${ }^{6}$ However, the model needs to be reconsidered in the light of contemporary practices which demonstrate that cultural memory is increasingly more dynamic. I take Assmann's model as a starting point for reflection, but I will re-work the model based on my own observations of television as a practice of cultural memory in the contemporary media environment. I will then carry out an analysis within the practical context of production and scheduling for television, to further explore the way in which new dynamic practices affect how television users can engage with the past as represented via the medium of television. The scheduling and production practices of the media platform Holland Doc, which includes the digital thematic channel Holland Doc 24, will be discussed as a prime example. As a result, television will be reconsidered as a practice of memory, demonstrating the mediated practice of active and passive remembering and forgetting in the multi-platform era.

\footnotetext{
2 See: José van Dijck, Mediated Memories in the Digital Age, Stanford University Press, 2007; Joanne Garde-Hansen, Media and Memory, Edinburgh University Press, 2011

3 Henry Jenkins, Convergence Culture: Where Old and New Media Collide, New York University Press, 2006, p. 112

4 Amy Holdsworth, Television, Memory and Nostalgia, Palgrave Macmillan, 2011; Mari Pajala, Television as an Archive of Memories? Cultural Memory and its Limits on the Finnish Public Service Broadcaster's Online Archive', Critical Studies in Television, 5, 2 (2010), p. 133-145; Andrew Hoskins, 'Television and the Collapse of Memory', Time Society, 13, 1 (2004), p. 109-27; Jérôme Bourdon, 'Some Sense of Time: Remembering Television', History and Memory, 15, 2 (2003), p. 5-35. The 2012 conferences 'Time Networks: Screen Media and Memory' (NECS, European Network for Cinema and Media Studies, New University of Lisbon and University of Coimbra) and the International Conference on New Media, Memories and Histories (Nanyang Technological University, Singapore) paid notable attention to television as a practice of memory.

5 Aleida Assmann, 'Canon and Archive', in: Astrid Erll and Ansgar Nünning, eds, Cultural Memory Studies: An International and Interdisciplinary Handbook, Walter de Gruyter, 2008, p. 98

6 Astrid Erll defines cultural memory as the interplay of present and past in socio-cultural contexts. Astrid Erll, 'Cultural Memory Studies: An Introduction', in: Astrid Erll and Ansgar Nünning, eds, Cultural Memory Studies: An International and Interdisciplinary Handbook, Walter de Gruyter, 2008, p. 2
} 


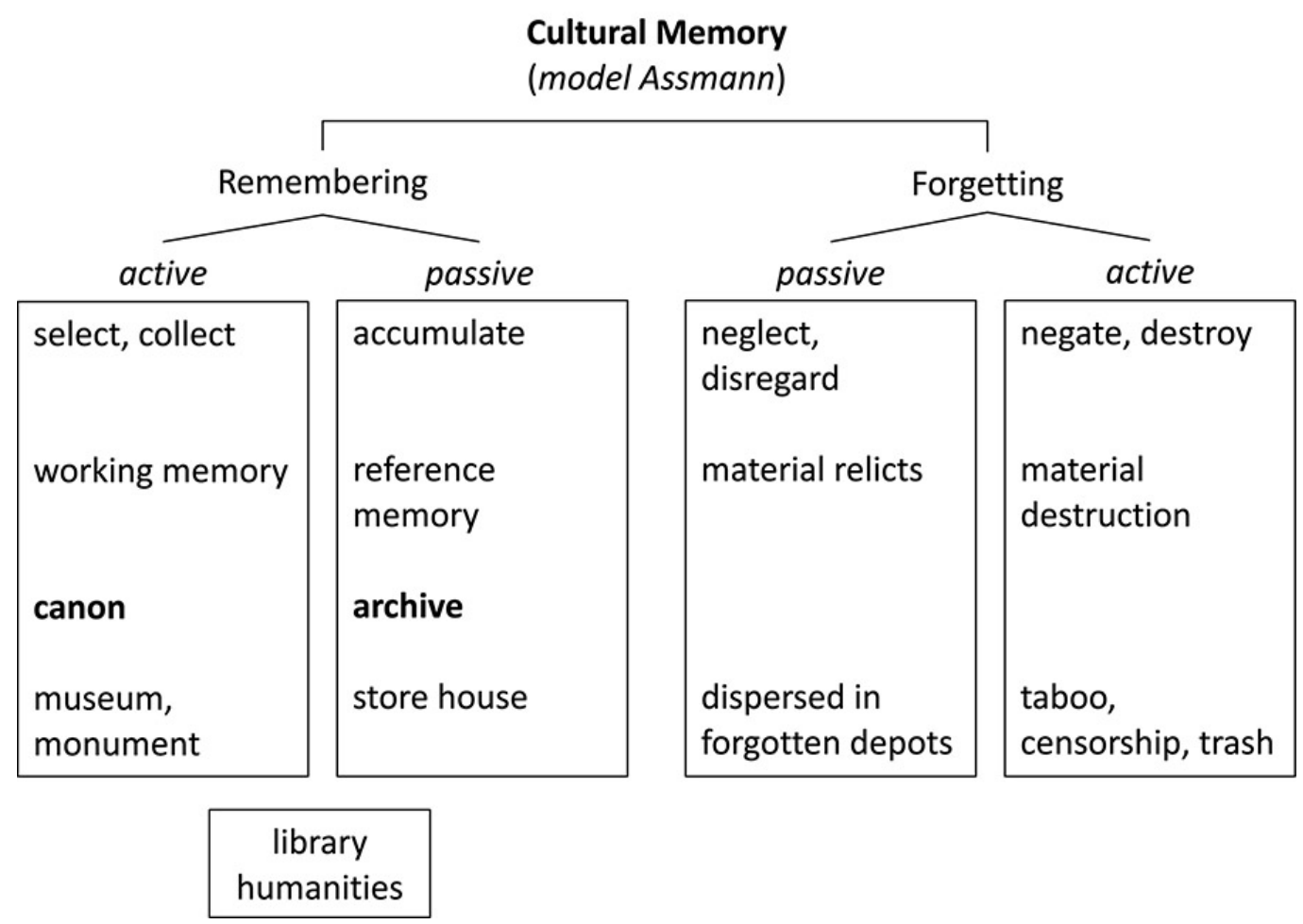

Fig.1 Model Assmann: Cultural memory. ${ }^{7}$

\section{Television As Cultural Memory}

Assmann has characterised memory as a highly selective practice. The institutions of active memory preserve the past as present, whereas the institutions of passive memory preserve the past as past. Specifically, actively circulated memory that keeps the past present is identified as the 'canon', made perceptible through practices of selection, value and duration. Passively stored memory that preserves the past as past is identified as the 'archive', denoting storehouses or stable repositories of information and power. The 'canon' can be compared to curated exhibits on display in a museum, and the 'archive' to objects hidden from the public's view in the storehouse. The former comprises texts with a sanctified status, destined to be repeated and re-read. The latter consists of disconnected cultural relics waiting for new interpretations. The cultural practice of forgetting also consists of two forms, a more active and a more passive one. A distinction is made between active intentional acts of forgetting, like material destruction, and passive non-intentional acts of forgetting, such as loss and negligence. ${ }^{8}$

The model 'Television as Cultural Memory' which I propose (Figure 2) outlines television as a practice of active and passive remembering and forgetting. In this model, I adopt and expand Assmann's theory of 'canon' and 'archive' in the context of television. The model demonstrates how television as cultural memory offers more dynamic, diverse forms of engagement with the past to different users and in particular, a wider range of opportunities to develop specific memory practices in the multi-platform era. 


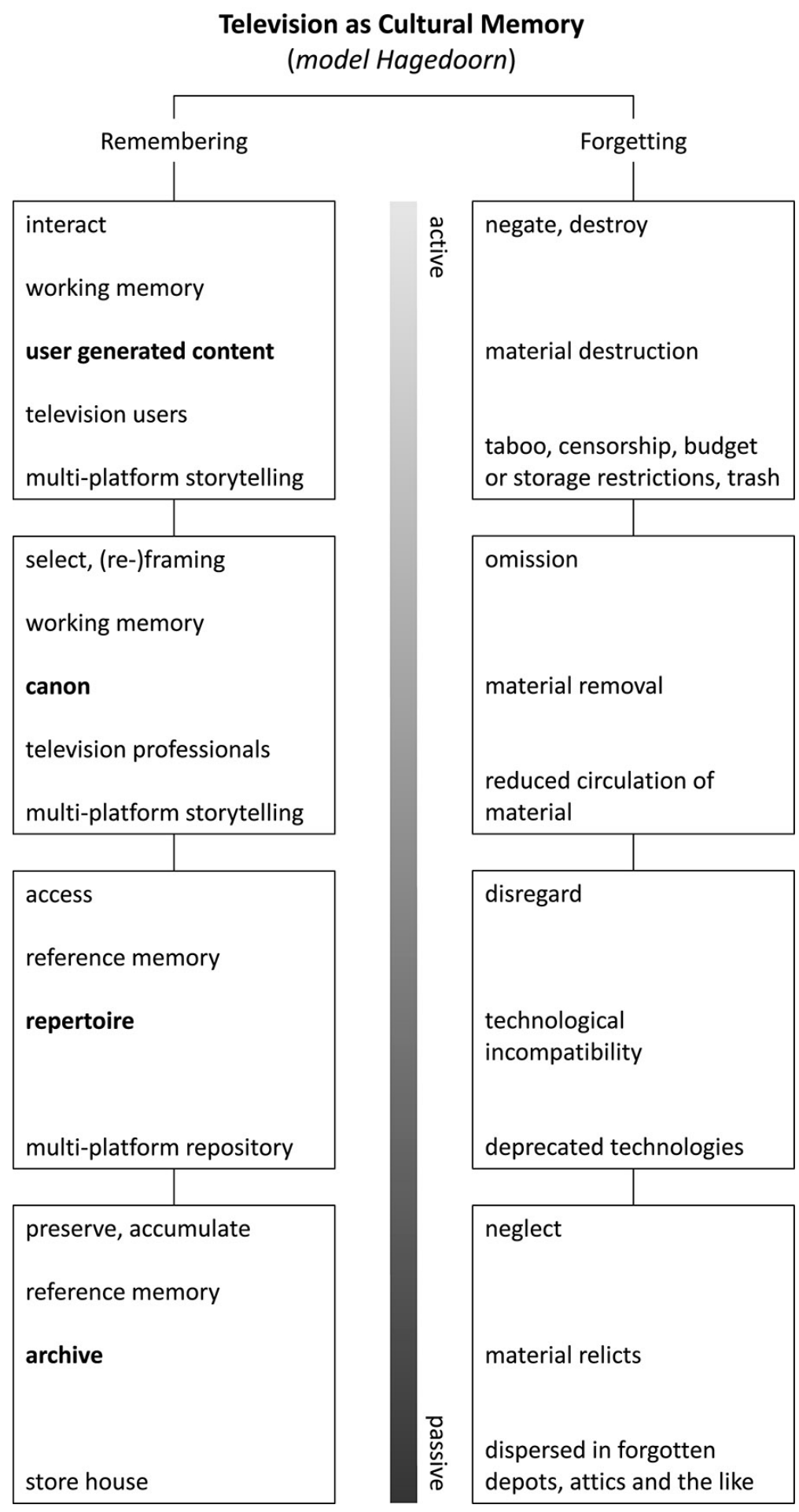

Fig. 2 Model Hagedoorn: Television as a practice of cultural memory in the multi-platform era, adopting and expanding Assmann's theory of 'canon and archive'. 
Assmann's original model needs to be reworked in a number of ways to map out contemporary dynamics. Rather than representing active and passive remembering (or forgetting) on opposite sides of a spectrum, the model I propose (Figure 2) represents a more dynamic spectrum. The different levels of active and passive engagement with the past by various users are made visible in vertical relation to one another. I outline different stages of remembering and forgetting (from more and most active, to less and least active or passive cultural practices). It is implied in horizontal relations which stage of active/passive remembering is more susceptible to which stage of active/passive forgetting (which does not mean it is invulnerable to other modes of forgetting). In this manner, the model emphasises the close connections between different forms of remembering and forgetting, and a more nuanced perspective on the degree of disconnection.

Different user roles in the active construction of a working memory are subsequently made explicit. Television professionals and television users both engage in cultural practices of multi-platform storytelling, contributing to the active (re-)construction of memory. I therefore make room for user interaction and the incorporation of 'user generated content'. The role of the television professional is emphasised on the level of selection and re-framing, resulting in the assembling of content for the 'canon'. The role of television professionals as curators in this manner includes the selection or collection of content for the 'canon', but also the (re-)framing and repurposing of broadcast materials on various platforms and screens. Interactive, participatory practices and content produced by television users need to be considered as a significant part of such a working memory. This is especially relevant considering that television users are more and more becoming like media producers in their own selection of and interaction with content. Assmann's work has demonstrated that elements of the canon can recede back into the archive, whilst elements of the archive can be recovered and reclaimed for the canon. ${ }^{9}$ In a similar manner, user generated content can recede into the canon (private memory narratives, audio-visual footage, comments on television content via social or personal media, to name but a few forms of user interaction). For example, the Dutch television canon of 60 definite titles is chosen by the Dutch public from a given programme selection via the website http://www.tvcanon.nl.

In contrast to Assmann's original model, I distinguish between two different forms of reference memory. The 'archive' functions as the storehouse for accumulation and preservation of audio-visual archival materials and knowledge thereof, including digitisation practices and the storing of apparatuses to screen or play particular audio-visual content. But in the multi-platform era, we need to consider another distinct mode of reference memory for television. Diana Taylor has made a useful distinction between the fixed, relatively stable objects in the archive and 'the socalled ephemeral repertoire of embodied practice/knowledge (i.e., spoken language, dance, sports, ritual)'. ${ }^{10}$ Whilst Taylor's definition of the concept 'repertoire' alludes more to embodied practices and performances, I utilise the concept 'repertoire' to make visible how television as cultural memory represents a more dynamic form of access to televisual content, which is dissimilar from the fixed mode of the archive. Television as a 'repertoire', then, is not a stable storehouse, but a multi-platform, cross-media repository which is more susceptible and vulnerable to changes over time. This repertoire consists of a wide, variable and changing range of possibilities to access televisual content across various screens and platforms. The conditions and time constraints under which these materials are accessible to professionals and viewers can vary, and are also subject to rights issues and other limits to material circulation. Via new digital technologies, users give active, personal interpretations to multi-platform repositories such as catch-up TV websites (e.g. the Dutch public broadcaster's Uitzending Gemist), video-sharing websites, and the Holland Doc media platform (which will be analysed below).

Finally, the model is further expanded by including technological incompatibility as an important form of disregard. This is particularly a possibility for the repertoire, which is less fixed and more likely to change or be prone to deprecated technologies in comparison to the archive-as-storehouse. Comparable to Assmann's model, material relicts are the most passive form of forgetting as neglect, and material destruction is the most active form of forgetting as negation or destruction. However, material removal is another important form of active forgetting as omission. For instance, the more active decisions by television professionals in not selecting particular content for the small screen, but also the reduced circulation of televisual content on a digital thematic channel due to a limited number of authorized reruns, as 
well as content made available online for a limited period.

Television as cultural memory draws our attention to the 'mediatedness' of memory texts as well as the politics of remembering and forgetting. The (re-)construction of narratives of the past through the medium of television is personally and collectively experienced within specific cultural and technological frameworks. Such experiences are shaped by the ways in which content is made accessible by television institutions as well as the personal engagement of television users with content. New digital technologies are the driving force behind the increasingly connected experiences offered and utilized by the medium television. In the following part of this article, I will therefore take a closer look at the hybridity of the medium, and carry out an analysis to further explore how new dynamic production and scheduling practices affect how television users can engage with the past.

\section{Hybridity: Mixing Broadcast Television And Digital Culture}

As the essays in the 2011 edited volume Television as Digital Media demonstrate, the practices of digital television have long been established within television in the broadcast era. ${ }^{11}$ Media theorists have mobilized a variety of concepts and descriptions to try and encompass the current transformation of the medium: from television in the 'digital age', ${ }^{12}$ television as a 'post-network, post-public service media system', ${ }^{13}$ to most recently, different forms of television programming in the 'post-network era'14, 'TViii', ${ }^{15}$ 'broadcast $2.0{ }^{\prime},{ }^{16}$ and television studies in the 'postbroadcast' era. ${ }^{17}$ According to Roberta Pearson, this 'post-television era' on the one hand reflects the relatively stable industrial conditions from the last part of the twentieth century, in which television still maintains its central position as a domestic medium. On the other hand, television programmes echo the increasingly unstable industrial conditions from the early twenty-first century, characterised by the continual convergence of media platforms and the fragmentation of audiences. ${ }^{18}$ Whilst notions like 'post-television', 'post-broadcast', 'post-public service' and 'postnetwork' are not meant to signal the irrelevance of broadcasting, public service, networks, or indeed, television, such descriptions do have a tendency to obscure the recent transformation of television into a multi-layered practice which includes long-established forms of public broadcasting as well as more contemporary practices like digital thematic channels.

Recent studies emphasize that we cannot speak of a simple shift from broadcasting to narrowcasting:

Digital television's screen does not simply replace the window; rather, it re-purposes, remediates, and constantly recalls and recirculates television's window-on-the-world positioning in the digital era. As often as we are promised the convenience of the television experience 'anytime, anywhere,' we are equally invited to participate in communities, share television moments, watch live now, come home to television, and structure our daily lives around TV. ${ }^{19}$

\footnotetext{
11 James Bennett and Niki Strange, eds, Television as Digital Media, Duke University Press, 2011

12 Jeanette Steemers, Changing Channels: The Prospects for Television in a Digital World, University of Luton Press, 1998, p. 97; Stylianos Papathanassopoulos, European Television in the Digital Age: Issues, Dynamics and Realities, Polity Press, 2002, p. 3

13 Lynn Spigel, 'Introduction', in: Lynn Spigel and Jan Olssen, eds, Television After TV: Essays on a Medium in Transition, Duke University Press, 2004, p. 1

14 Amanda D. Lotz, Beyond Prime Time: Television Programming in the Post-Network Era, Routledge, 2009, p. 7

15 Mark C. Rogers, Michael Epstein and Jimmie L. Reeves, 'The Sopranos as HBO Brand Equity: The Art of Commerce in the Age of Digital Reproduction,' in: David Lavery, ed, This Thing of Ours: Investigating The Sopranos, Columbia University Press, 2002, p. 46

16 Anthony Rose, 'How iPlayer will become our player for your friends,' 10 December 2008, http://www.quardian.co.uk/media/2008/dec/11/interview-anthony-rose-iplayer, Accessed 20 May 2013

17 Graeme Turner and Jinna Tay, eds, Television Studies After TV: Understanding Television in the Post-Broadcast Era, Routledge, 2009, p. 5

18 Roberta Pearson, 'Lost in Transition. From Multi-platform to Post-Television', in: Janet McCabe and Kim Akass, eds, Quality TV: Contemporary American Television and Beyond, I.B. Tauris \& Co Ltd, 2007 , p. $239-40$

19 James Bennett, 'Introduction: Television as Digital Media', in: James Bennett and Niki Strange, eds, Television as Digital Media, Duke University Press, 2011, p. 5; See also: James Bennett, 'Your Window on the World: The Emergence of Red-Button Interactive Television in the UK', Convergence: The Journal of Research into New Media Technologies, 14, 2, 2008, p. 161-182
} 
New digital technologies also offer growing opportunities to pack numerous facilities into a multi-fractured device or service. One of the key developments in the televisual landscape is hybrid TV or connected TV, meaning the acquisition of services via the direct connection of television with new digital media forms - from live television broadcasts to on demand viewing and gaming practices. 'The future is hybrid' proclaims the European Broadcasting Union (EBU) in its June 2012 Viewpoint publication. ${ }^{20}$ The hybrid revolution entails devices and services utilizing both the digital broadcast network as well as broadband connections, linking the networks of television and internet together on one screen (with one remote control). Since most TVs sold will be able to connect to the internet by 2014 (although this absolutely does not entail that all bought sets will be web-connected by their owners), the EBU argues that common solutions linking television and internet will encourage more competition between suppliers, lowers costs and offers more choice for consumers. For the moment, important factors such as the number of viewers relying on the terrestrial television platform and the penetration of DTT services ${ }^{21}$ influence the situation in individual countries. The implementation of hybrid TV or connected TV depends greatly on the type of viewing culture, regulations and infrastructure in each country.

Consequently, television is mixed in with digital culture across different infrastructures and timelines.

\section{Holland Doc: Looking At The World With Different Eyes}

The documentary platform of Dutch public television, Holland Doc, demonstrates how a repertoire of texts is actively circulated via television as a constellation of connected, curated practices. As a textual composite, the platform represents the medium's hybridity by mixing practices from traditional public broadcasting (including cultural practices like radio) with new digital media forms. A critical analysis of the Holland Doc platform can shed light on how television's hybridity flows from the cross-media circulation of content.

Holland Doc exemplifies the multifaceted way of looking at and gaining access to television programming through a variety of 'connected' texts in the contemporary media landscape. The Holland Doc platform encompasses four media texts, which are:

- the documentary feature programme Holland Doc, broadcast weekly on the second Dutch public television channel;

- the digital thematic channel Holland Doc 24;

- Holland Doc radio, the weekly broadcast of a short and a long documentary on public service channel Radio 1;

- and finally, the website Holland Doc.nl, which offers a live stream of the digital documentary channel, plus more than 1000 television and radio documentaries on demand, as well as background information with documentaries, news, and interviews with documentary makers. 


\section{Access To The Holland Doc Repertoire}

The viewer's attention is dispersed across a range of information points, which can also trigger audiences 'where to look' or to link present, historical and/or archival content from one platform to another. For example, the Holland Doc website offers visitors a variety of entry points to access its television and radio programming and online archive. The homepage (see Figure 3) disperses the visitor's attention across a range of information triggers, prompting the audiences' interest by highlighting specific programming ('spotlight'), drawing attention to programming in 'theme weeks', recent broadcasts to catch up with, and a main emphasis on the Holland Doc 24 live stream. Visitors on the portal can browse through a selection of key themes on the homepage, to access connected television and radio documentaries and actively engage with the media texts in the repertoire.
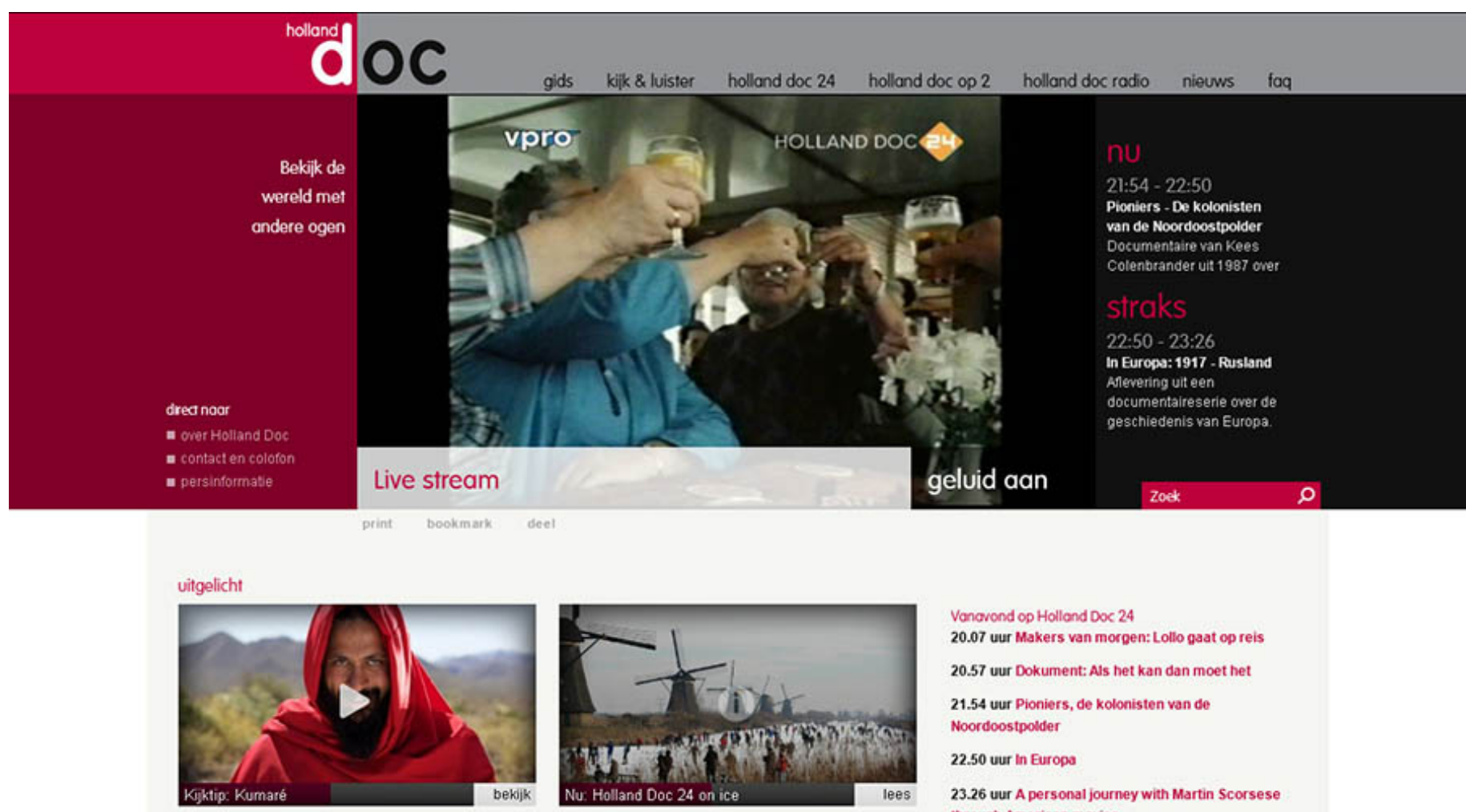

Vanavond op Holland Doc 24

20.07 uur Makers van morpen: Lollo gaat op reis

20.57 uur Dokument: Als het kan dan moet het

21.54 uur Pioniers, de kolonisten van de

Noordoostpolder

22.50 uur in Europa

23.26 uur A personal journey with Martin Scorsese

through American movies

documentaire gemist

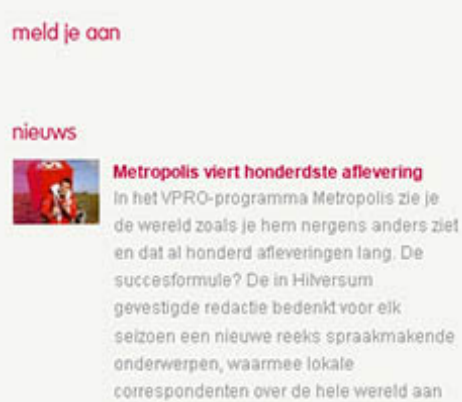

Holland Doc 24 in 2013

Themaweek: Op trandje

Themaweek: Holland Doc 24 on ice

Themaweek: Kijk je slank op de bank

Themaweek: Feelgood documentaires

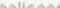
meest uitgebreide fotografie project ooit: cen serie beßemmende, surrealistischi. portretten van het leven in Weine Amerikaanse dorpen.

Holland Doc: Kumaré

Sceptisch oververlichte goeroes beslut de filmmaker als experiment zelf goeroe te worden en krigt al snel veel trouwe

correspondenten over de hele wereld aan

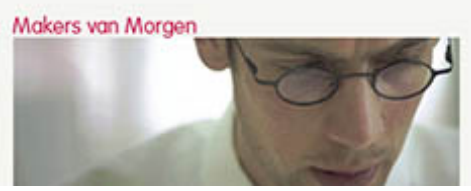

Fig 3. Homepage Holland Doc.nl (Source: www.hollanddoc.nl, 13 January 2013) 
The hybridity of the platform is made visible through the dispersed access to a wide range of programmes. In April 2012, the documentary channel Holland Doc merges with the historical channel Geschiedenis 24 ('History 24') the latter retaining its function as an online web portal into the public broadcaster's historical content. The newly launched digital channel Holland Doc 24 broadcasts historical, social and scientific documentaries. The channel's main goal is to open up access to (previously broadcast) documentary programming and to provide more in-depth understanding with documentary content for Dutch audiences. Audiences can also interact and engage with content via YouTube, Facebook, Twitter and newsletters, as well as by commenting on content on the Holland Doc website. The audio/visual content which Holland Doc offers can be experienced by viewers in the Netherlands via a variety of entry points, whether it's a laptop, PC or tablet with internet access; digital television; radio; or analogue viewing via cable television. This will frame for how long, to how many and to what kind of representations of the past, as transmitted via the Holland Doc platform, audiences have access.

\section{Monthly users Holland Doc multimedia platform in 2012}

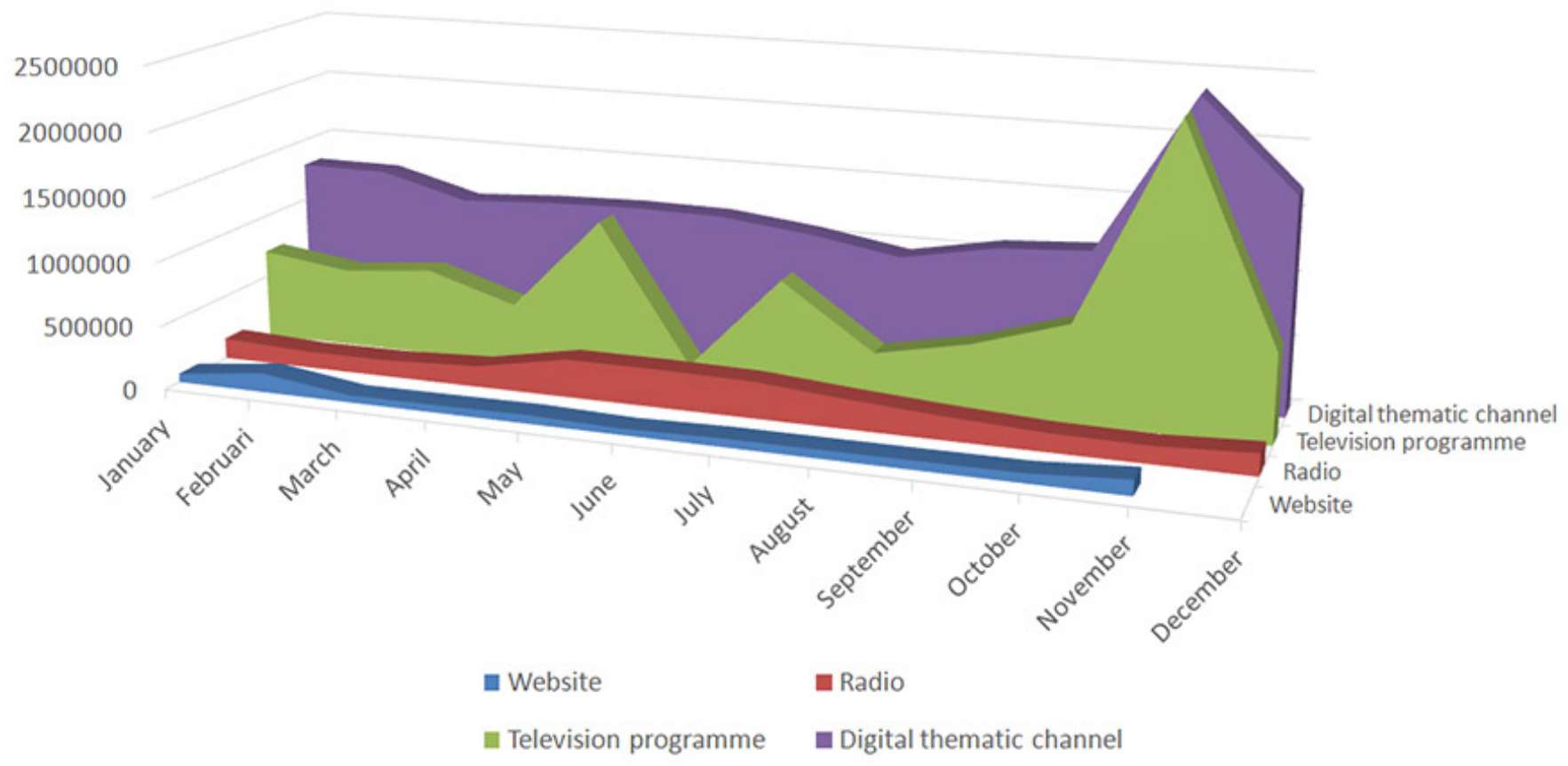

Figure 4: Monthly users Holland Doc multimedia platform in 2012

Data courtesy of: Nederlandse Publieke Omroep, Kijk-en Luisteronderzoek (KLO)

This graph (Figure 4) provides an overview of the cumulative number of visitors per month for the Holland Doc website, television programme, radio programme and digital thematic channel between January and NovemberDecember 2012. The graph points towards correlations between the television programme and the digital thematic channel, whilst audience figures for the radio programme and website remain relatively stable. Website visits are consistent throughout the year, with peaks in February and November. The second Dutch public channel generally broadcasts four to five Holland Doc documentaries per month, with the exception of May (six documentaries), November (10 documentaries) and June (one documentary). Interestingly, whilst public service broadcasting often functions as a main motivator or incentive for the amount of website visits, the fact that 'only' one Holland Doc documentary was screened on the public service channel in June has not seemed to shake visiting figures for the other three platforms. Holland Doc 24 has been made available (without additional costs) on the event channels of two of the largest cable operators in the Netherlands during the International Documentary Festival Amsterdam (14-25 November 2012) which can account for the additional viewing figures in this period. 
Holland Doc's slogan is 'look at the world with different eyes'. As such, the platform provides access to a specific repository of media texts. The programming is generally targeted towards a relatively smaller niche audience defined as 'de kritische verdiepingzoeker', the critical viewer (approximately 35+) looking for in-depth and background information. Thematic channels often offer content which is, for a variety of reasons, less visible on main public channels. This is the case for Holland Doc: not only has documentary programming in the Netherlands been defined as a 'vulnerable artistic product'22 but digital channel Holland Doc 24 also offers room for experimentation and a podium for newcomers. Contrary to its name, Holland Doc transcends national borders and connotations. The platform's editorial staff is based at Dutch public broadcaster VPRO, but documentaries are derived from various broadcasting licence holders, in and outside of the Netherlands. For the past few years, digital channel Holland Doc 24 has also provided a 'Makers of Tomorrow' timeslot, where students and young European documentary makers can broadcast their work. By scheduling television programmes 24/7, Holland Doc 24 provides access to current and timehonoured documentaries previously aired on the second public channel, in-house produced or acquired from abroad. In this manner, the range of programmes screened as well as the strategies used by their documentary makers to represent the past on the small screen is incredibly varied. The platform therefore places a main emphasis on the contextualisation of content.

\section{Cross-Platform Scheduling}

The scheduling on the Holland Doc platform demonstrates how television professionals actively participate in practices of selection and (re-)framing, thus creating a 'canon'. Due to the emphasis on pre-selection, scheduling in the context of a digital thematic channel can be compared to the role of a curator. The channel provides access to memory texts via a different strategy than 'traditional' broadcast television: by functioning as a 'thematic periodical' ${ }^{23}$ based on a selection of topical as well as recurring themes. For instance, at least two historical documentaries within a theme are featured per week or programming may be inspired by a specific historical event. Weekly themes can be based on an anniversary or commemoration (Liberation Day), a particular broadcast or historical media event (the broadcast of Nederland valt aan ('The Netherlands Attack') (2012), a special media event offering a reconstruction of the first day of the Dutch war in the Dutch East Indies, forms the occasion for a theme week on the Dutch East Indies), a museum exhibition, a book launch, a documentary film festival, and so on. Links with actuality are thus key, but lead to a contradiction in the audiovisual content which can be offered on different platforms. The online website has the means to be particularly topical and single out documentaries that tie in with current affairs on its homepage. Media events have the power to disrupt the scheduled flow of content, but the internet platform and Facebook page provide the opportunity to respond to actual events much quicker. However, a digital thematic channel cannot be that topical. A 24/7 broadcasting schedule, with many different types of content, demands that the editorial staff should look far ahead - even as far as a year in advance. The acquisition of documentaries also takes time. Therefore, 'actuality' in the context of the digital thematic channel is more a 'ritualized' form of actuality, where scheduling is devised to dovetail with important dates (anniversaries, commemorations) and events, so that programming can be scheduled well in advance.

The importance of pacing and timing of the schedule is demonstrated by the re-broadcast of Michael Apted's Up series (1964-2012), in which members of the same group of British people are interviewed on a range of subjects every seven years. According to Holland Doc 24 editor-in-chief, Hansje van Etten, the entire Up series is not only history of the last 50 years, but also part of the collective memory of a specific group of Dutch viewers, particularly the VPRO-viewer: 'Taking myself as an example, I have kept up with the series throughout the years, and you tend to get very attached to these people (...) you sympathise with them, you are a part of that generation. ${ }^{.24}$ Although Michael

22 'Minder documentaires bij Publieke Omroep', 3 March 2007, http://www.hollanddoc.nl/nieuws/2007/maart/Minder-documentaires-bii-Publieke-Omroep.html, Accessed 20 May 2013

23 Eggo Müller, 'Televisie in een convergerend medialandschap, 1995-2010', in: Bert Hogenkamp, Sonja de Leeuw, Huub Wijjes, Een Eeuw van Beeld en Geluid, Nederlands Instituut voor Beeld en

Geluid, 2012, p. 290

24 Hansje van Etten, personal interview, Hilversum, 27 November 2012 
Apted has had to re-adjust his principal argumentation concerning Britain as a class society, the documentary series provides insights into various changes that have occurred in Western society throughout the last 50 years. Apted's most recent endeavour, 56 Up (2012), is broadcast on Dutch public television in three parts on January 2-4, 2013. In the run-up to the broadcast, the preceding chapters in the series are re-broadcast week by week in late 2012, producing a 'build-up' similar to the long-doc format itself, albeit in a condensed fashion. (Promo re-run 'Up series' on Holland Doc 24)

Next to the weekly themes, programmes are scheduled at specific points in the week's broadcasting schedule to make meaningful connections with historical programmes broadcast on public television or radio. For instance, a public broadcast of the history programme Andere Tijden ('Different Times') (2012) on asbestos is directly followed by the documentary Asbest: The Silent Killer (1996) on Holland Doc 24; or a public broadcast of the historical documentary De Gouden Eeuw ('The Golden Age') (2012) will be followed by the broadcast of a documentary on Dutch painter Rembrandt van Rijn on Holland Doc 24. Promotion is essential here to connect users with content across platforms, and to keep users informed and up-to-date of the schedule (via television, TV guide, Facebook, Twitter). The platform utilises (cross-)promotion, weekly promos and monthly promos on its various screens, including YouTube.

\section{In-House Productions As Practices Of Contextualization}

Selected programmes for the 'canon' are (re-)framed and contextualised to offer television users a more in-depth experience. Such practices of contextualisation work towards a deeper engagement of television users with media texts and a better understanding of selected texts. In particular, Holland Doc 24 further contextualises its own scheduled programming by means of in-house productions. These short productions are also made available via YouTube, to spark interest for a particular broadcast. For example, in advance of the weekly documentary 'classic', a 5 minute short is scheduled in which the selected documentary is introduced and explained by presenter Daphne Bunskoek - modernizing the traditional role of the television presenter - and visualized by means of noteworthy fragments. (Daphne Bunskoek introduces the documentary classic Bread Day (Russia, 1999). NB: This introduction is placed on YouTube on 12 November 2012, with the broadcast subsequently scheduled for 30 November 2012.)

Such productions not only provide contextualisation with broadcast materials, but make visible the process of selection and scheduling by television professionals for the canon. For instance, the same documentary, Bread Day (Russia, 1999), has also been discussed in Docugasten ('Docu Guests') (2008-), where 'guest-programmers' are invited to participate in the selection of documentary content and to explain their choices on camera. In the episode aired on 9 October 2010, documentary maker Heddy Honigmann, whose work is extensively featured on the Holland Doc website, explains why she chooses to schedule the Russian documentary Bread Day. The item reveals why Honigmann believes that documentaries such as Bread Day should be produced. (Heddy Honigmann on scheduling Bread Day: Docugasten ('Docu-quests'), episode 9 October 2010)

Both these productions are available via the Holland Doc website, the platform's YouTube channel, and have also been scheduled on the digital thematic channel. 


\section{Unity In Fragmentation}

John Ellis has argued that scheduling is the 'locus of power in television'25 - a cornerstone of television which has scarcely been studied academically. On the one hand, because the viewer is no longer bound to specific programming when watching television and audiences have become fragmented, the locus of power of the schedule as it was in the broadcast era seems to be lost. Television can no longer dictate what and when people watch as it did before. On the other hand, because of the experience of interconnected and related content, television does provide possibilities for a 'unity in fragmentation'26 by mobilising audiences from one platform or programme to the next. In the case of deliberately timed cross-promotions and connected broadcasts, this can occur within a similar timeframe, comparable to the shared experience of television in the broadcast-era. The digital thematic channel offers a $24 / 7$ scheduled flow of programmes that enhance one another, whilst the Holland Doc platform as a whole can be regarded as an extension of television programming. As a result, previously broadcast material is repurposed by positioning television programmes in new historical and televisual contexts.

The analysis of the Holland Doc platform above focuses chiefly on the platform's circulation of content as a practice of cultural memory, which includes a dynamic spectrum of active and passive forms of remembering: from the selection and (re-)framing of memory materials to providing access to a repertoire of connected texts. However, these practices are subordinate to active and passive forms of forgetting. The scheduling and pacing of content for the canon as working memory is mostly subject to more active forms of forgetting, which can include how long a certain programme is made available on demand, how many times a programme is allowed to be rerun on a specific digital channel, budget restrictions, copyright issues, and other forms of omission or negation. Forms of user interaction can also recede into the canon, for instance by television users offering suggestions for documentaries via Facebook. When content remains accessible (as reference memory) by receding into the repertoire, technological incompatibility as a more passive form of forgetting can also impede upon the access to the multi-platform repository.

\section{Television As A Hybrid Repertoire Of Memory}

Television is an increasingly dynamic and complex 'tool' for engagement with the past. Essentially, the way in which television professionals and users give meaning to television as a memory practice is both enabled and impeded by the hybrid form in which television is currently present in everyday life. Television in the digital landscape can in this manner be compared to a media interface. Starting from the time-honoured metaphor of television as a 'window on the world', Karen Orr Vered argues that television content is increasingly stylized to suggest an interface where the viewer's attention is dispersed across a range of information cues. ${ }^{27}$ The concept of 'interface' points to the fact that television content is made available to users via various entry points, which also include information triggers (links, promos, pop-up textual or visual information) that can direct our attention and link content across platforms. On the one hand, the interface metaphor sheds light on the move from a programming based notion of 'flow' towards an increasingly 'viewer centred' and 'technologically ordered concept of flow'. ${ }^{28}$ In this context, James Bennett states that online streaming and download services such as the BBC iPlayer dislocate programmes from the scheduled flow of television. The television audience is fragmented into a series of increasingly personalised experiences and choices by providing on demand access to television programmes as a form of audiovisual content to be watched whenever, wherever, on whatever device. ${ }^{29}$ On the other hand, television as a media interface - or indeed, media interfaces - is

25 John Ellis, 'Scheduling: the last creative act in television?', Media, Culture and Society, 22, 25, 2000, p. 25-26.

26 Marc Andrejevic, 'The twenty-first-century telescreen', in: Graeme Turner and Jinna Tay, eds, Television Studies After TV: Understanding Television in the Post-Broadcast Era, Routledge, 2009, p. 39-40 27 Karen Orr Vered, 'Televisual Aesthetics in Y2K: From Windows on the World to a Windows Interface, Convergence: The Journal of Research into New Media Technologies, 8, 3, Autumn 2002, p. 41-2 28 William Uricchio, 'Television's Next Generation: Technology/Interface, Culture/Flow, in: Lynn Spigel and Jan Olssen, eds, Television After TV: Essays on a Medium in Transition, Duke University Press, 2004, p. 163-82

29 James Bennett, 'Introduction: Television as Digital Media', in: James Bennett and Niki Strange, eds, Television as Digital Media, Duke University Press, 2011, 1-2. 
an everyday experience situated within 'complex industrial flows of a twenty-first-century media industry'. ${ }^{30}$ It reminds us that the medium now consists of a mixture of distinct platforms and screens which structure our experience of viewing and interaction with audiovisual content.

As the Holland Doc platform demonstrates, television today opens up access to a hybrid 'repertoire' of connected cultural texts made available across multiple platforms and screens. The study of television as a practice of cultural memory therefore not only needs to include the study of memory materials, but also the manner in which this content is curated and made available to the public by television professionals. Re-working Assmann's model of cultural memory based on observations of television as a practice of cultural memory is a first step in this direction. The new model emphasizes the interplay of present and past in contemporary televisual environments. Television is being increasingly stylized as a media interface, where the viewer's attention is dispersed across a range of entry points and information triggers. Television as a hybrid 'repertoire' of memory illuminates how texts from the canon may faster recede into the repertoire, but also bring about new opportunities to reclaim and recontextualize texts for the canon, demonstrating the more dynamic mediated practice of active and passive remembering and forgetting in the multiplatform era. Fundamentally, television is a facilitator for the more dynamic ways in which memory content is circulated and made sense of today. Television in the multi-platform era offers a wider range of forms of engagement and connections with the past to different users. The medium's contemporary dynamics as a textual composite therefore need to be further explored.

\section{Acknowledgements}

I would specifically like to thank Sonja de Leeuw and the anonymous reviewers for their valuable comments. Hansje van Etten and Anya Boelhouwer (Holland Doc 24) are thanked for their participation in an interview for the preparation of this article.

\section{B i o graphy}

Berber Hagedoorn, MA is a lecturer and PhD candidate in Media and Culture Studies at Utrecht University, the Netherlands. Hagedoorn researches multi-platform television, transmedia storytelling, cultural memory and the reuse of archival footage in a variety of media platforms, particularly documentary and historical programming. She has published in amongst others the academic journals Studies in Documentary Film, Rundfunk und Geschichte and Tijdschrift voor Mediageschiedenis (Journal of Media History). Hagedoorn is writing a dissertation on the topic of 'Repurposing Television's Past: Re-screening, History and Memory in the Multi-Platform Era' and is currently working as a researcher for the project 'EUscreenXL, the pan-European audiovisual aggregator for Europeana'. Her work on Dutch multi-platform TV documentary and the performance of the cultural memory of the Holocaust will appear in the forthcoming edited volume Holocaust Intersections: Genocide and Visual Culture at the New Millennium (Eds. Bangert, Gordon \& Saxton, Legenda 2013). Hagedoorn is a member of the European Television History Network, Utrecht University's Centre for Television in Transition, Vereniging Geschiedenis, Beeld en Geluid (The Association of History, Image and Sound) and the RMeS Research School for Media Studies.

30 David Chamberlain, 'Scripted Spaces: Television Interfaces and the Non-Places of Asynchronous Entertainment', in: James Bennett and Niki Strange, eds, Television as Digital Media, Duke University Press, 2011, p. 233 